\title{
Front Matter: Volume 8596
}

, "Front Matter: Volume 8596," Proc. SPIE 8596, Reporters, Markers, Dyes, Nanoparticles, and Molecular Probes for Biomedical Applications V, 85961A (4 April 2013); doi: 10.1117/12.2021953

SPIE. Event: SPIE BiOS, 2013, San Francisco, California, United States 


\title{
Reporters, Markers, Dyes, Nanoparticles, and Molecular Probes for Biomedical Applications V
}

\author{
Samuel Achilefu \\ Ramesh Raghavachari \\ Editors
}

4-6 February 2013

San Francisco, California, United States

Sponsored and Published by

SPIE

Volume 8596 
The papers included in this volume were part of the technical conference cited on the cover and title page. Papers were selected and subject to review by the editors and conference program committee. Some conference presentations may not be available for publication. The papers published in these proceedings reflect the work and thoughts of the authors and are published herein as submitted. The publisher is not responsible for the validity of the information or for any outcomes resulting from reliance thereon.

Please use the following format to cite material from this book:

Author(s), "Title of Paper," in Reporters, Markers, Dyes, Nanoparticles, and Molecular Probes for Biomedical Applications $V$, edited by Samuel Achilefu, Ramesh Raghavachari, Proceedings of SPIE Vol. 8596 (SPIE, Bellingham, WA, 2013) Article CID Number.

ISSN: 1605-7422

ISBN: 9780819493651

Published by

SPIE

P.O. Box 10, Bellingham, Washington 98227-0010 USA

Telephone +1 3606763290 (Pacific Time) · Fax +1 3606471445

SPIE.org

Copyright (c) 2013, Society of Photo-Optical Instrumentation Engineers.

Copying of material in this book for internal or personal use, or for the internal or personal use of specific clients, beyond the fair use provisions granted by the U.S. Copyright Law is authorized by SPIE subject to payment of copying fees. The Transactional Reporting Service base fee for this volume is $\$ 18.00$ per article (or portion thereof), which should be paid directly to the Copyright Clearance Center (CCC), 222 Rosewood Drive, Danvers, MA 01923. Payment may also be made electronically through CCC Online at copyright.com. Other copying for republication, resale, advertising or promotion, or any form of systematic or multiple reproduction of any material in this book is prohibited except with permission in writing from the publisher. The CCC fee code is $1605-7422 / 13 / \$ 18.00$.

Printed in the United States of America.

Publication of record for individual papers is online in the SPIE Digital Library.

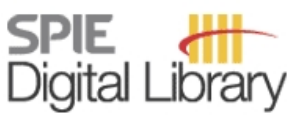

SPIEDigitalLibrary.org

Paper Numbering: Proceedings of SPIE follow an e-First publication model, with papers published first online and then in print and on CD-ROM. Papers are published as they are submitted and meet publication criteria. A unique, consistent, permanent citation identifier (CID) number is assigned to each article at the time of the first publication. Utilization of CIDs allows articles to be fully citable as soon as they are published online, and connects the same identifier to all online, print, and electronic versions of the publication. SPIE uses a six-digit CID article numbering system in which:

- The first four digits correspond to the SPIE volume number.

- The last two digits indicate publication order within the volume using a Base 36 numbering

system employing both numerals and letters. These two-number sets start with 00, 01, 02, 03, 04, $05,06,07,08,09,0 A, 0 B \ldots 0 Z$, followed by 10-1Z, 20-2Z, etc.

The CID Number appears on each page of the manuscript. The complete citation is used on the first page, and an abbreviated version on subsequent pages. Numbers in the index correspond to the last two digits of the six-digit CID Number. 


\section{Contents}

vii Conference Committee

\section{MOLECULAR PROBES FOR TARGETED IMAGING AND THERAPY}

859602 ICG-loaded polymeric nanocapsules functionalized with anti-HER2 for targeted fluorescence imaging and photodestruction of ovarian cancer cells [8596-2]

B. Bahmani, Y. Guerrero, V. Vullev, Univ. of California, Riverside (United States); S. P. Singh, V. Kundra, Univ. of Texas MD Anderson Cancer Ctr. (United States); B. Anvari, Univ. of California, Riverside (United States)

859603 In vivo imaging of tumor vascular endothelial cells [8596-3]

D. Zhao, J. H. Stafford, H. Zhou, P. E. Thorpe, The Univ. of Texas Southwestern Medical Ctr. (United States)

\section{NIR FLUORESCENT MOLECULAR PROBES FOR BIOLOGICAL IMAGING}

859604 NIR fluorescent dyes: versatile vehicles for marker and probe applications (Invited Paper) [8596-4]

G. Patonay, G. Chapman, G. Beckford, M. Henary, Georgia State Univ. (United States)

859605 Covalent IR820-PEG diamine conjugates: characterization and in vivo biodistribution [8596-5]

A. Fernandez-Fernandez, Florida International Univ. (United States) and Nova Southeastern Univ. (United States); R. Manchanda, Florida International Univ. (United States);

D. A. Carvajal, Mount Sinai Medical Ctr. (United States); T. Lei, A. J. McGoron, Florida International Univ. (United States)

859606 Near-infrared light-triggered dissociation of block copolymer micelles for controlled drug release [8596-6]

J. Cao, S. Huang, Y. Chen, S. Li, China Pharmaceutical Univ. (China); S. Achilefu, Washington Univ. in St. Louis (United States); Z. Qian, Nanjing Univ. of Aeronautics and Astronautics (China); Y. Gu, China Pharmaceutical Univ. (China)

859607 Near-infrared imaging loaded polymeric nanoparticles: in vitro and in vivo studies [8596-7] T. Lei, R. Manchanda, Y.-C. Huang, Florida International Univ. (United States);

A. Fernandez-Fernandez, Florida International Univ. (United States) and Nova Southeastern Univ. (United States); K. Bunetska, A. Milera, A. Sarmiento, A. J. McGoron, Florida

International Univ. (United States) 
IMAGING MOLECULAR PROCESSES WITH FLUORESCENT REPORTERS

859609 Fluorescent proteins as singlet oxygen photosensitizers: mechanistic studies in photodynamic inactivation of bacteria [8596-9]

R. Ruiz-González, Univ. Ramon Llull (Spain); J. H. White, The Univ. of Edinburgh (United Kingdom); A. L. Cortajarena, Madrid Institute for Advanced Studies in Nanoscience (Spain); M. Agut, S. Nonell, Univ. Ramon Llull (Spain); C. Flors, Madrid Institute for Advanced Studies in Nanoscience (Spain)

$85960 \mathrm{~A}$ Investigating real-time activation of adenosine receptors by bioluminescence resonance energy transfer technique [8596-10]

Y. Huang, H. Yang, L. Zheng, J. Chen, Y. Wang, H. Li, S. Xie, Fujian Normal Univ. (China)

NONBLEACHING AND ULTRASMALL FLUORESCENT TAGS II: JOINT SESSION WITH CONFERENCES 8596 AND 8635

$85960 \mathrm{C}$ Probing intra-cellular drug release event using activatable (OFF/ON) CdS:Mn/ZnS quantum dots (Qdots): spectroscopic studies to investigate interaction of Qdots with quencher (Invited Paper) [8596-12]

J. Tharkur, A. Teblum, S. Basumallick, R. Shah, K. Cantarero, N. Maity, S. Rifai, M. Doshi, Univ. of Central Florida (United States); A. J. Gesquiere, The College of Optics and Photonics, Univ. of Central Florida (United States); S. Santra, Univ. of Central Florida (United States)

8596 OD Lanthanide-doped nanoparticles for hybrid x-ray/optical imaging [8596-13]

L. Sudheendra, G. K. Das, Univ. of California, Davis (United States); C. Li, Univ. of California, Davis (United States) and Univ. of California, Merced (United States); S. R. Cherry,

I. M. Kennedy, Univ. of California, Davis (United States)

\section{NANOPARTICLES FOR BIOLOGICAL APPLICATIONS}

8596 ol Molecular thermometers for potential applications in thermal ablation procedures (Invited Paper) [8596-19]

N. G. Zhegalova, A. Aydt, S. T. Wang, M. Y. Berezin, Washington Univ. School of Medicine in St. Louis (United States)

SOFT NANOPARTICLES FOR BIOMEDICAL APPLICATIONS

$8596 \mathrm{OL}$ Suppressing inflammation from inside out with novel NIR visible perfluorocarbon nanotheranostics (Invited Paper) [8596-21]

J. M. Janjic, S. K. Patel, Duquesne Univ. (United States); M. J. Patrick, Carnegie Mellon Univ.

(United States); J. A. Pollock, E. DiVito, M. Cascio, Duquesne Univ. (United States)

\section{HYBRID TECHNOLOGIES FOR MOLECULAR IMAGING APPLICATIONS}

859600 Engineering a lifetime-based activatable probe for photoacoustic imaging [8596-25]

E. Morgounova, Q. Shao, B. Hackel, S. Ashkenazi, Univ. of Minnesota (United States)

iv 
8596 OP Polyacrylamide based ICG nanocarriers for enhanced fluorescence and photoacoustic imaging [8596-26]

A. Ray, H. K. Yoon, H. Ryu, Y.-E. Koo Lee, G. Kim, X. Wang, R. Kopelman, Univ. of Michigan (United States)

8596 OR Photothermal detection of the contrast properties of polypyrrole nanoparticles using optical coherence tomography [8596-28]

D. Kasaragod, K. M. Au, Z. Lu, D. Childs, S. P. Armes, S. J. Matcher, Univ. of Sheffield (United Kingdom)

\section{MOLECULAR APPROACHES AND METHODS}

8596 OT Predicting errors from spectral overlap in multi-probe and multi-laser flow cytometry [8596-30]

M. Potasek, E. Parilov, K. Beeson, Simphotek Inc. (United States)

8596 OU Intracellular delivery of molecular beacons by PMMA nanoparticles and carbon nanotubes for mRNA sensing [8596-31]

A. Giannetti, S. Tombelli, C. Trono, Istituto di Fisica Applicata Nello Carrara, Consiglio Nazionale delle Ricerche (Italy); M. Ballestri, Istituto per la Sintesi Organica e la Fotoreattività, Consiglio Nazionale delle Ricerche (Italy); G. Giambastiani, Istituto di Chimica dei Composti OrganoMetallici, Consiglio Nazionale delle Ricerche (Italy); A. Guerrini, G. Sotgiu, Istituto per la Sintesi Organica e la Fotoreattività, Consiglio Nazionale delle Ricerche (Italy); G. Tuci, Istituto di Chimica dei Composti OrganoMetallici, Consiglio Nazionale delle Ricerche (Italy); G. Varchi, Istituto per la Sintesi Organica e la Fotoreattività, Consiglio Nazionale delle Ricerche (Italy); F. Baldini, Istituto di Fisica Applicata Nello Carrara, Consiglio Nazionale delle Ricerche (Italy)

\section{POSTER SESSION}

8596 OY Single molecule interactions studied by using a modified DNA sequencer: a comparison with surface plasmon resonance [8596-35]

J. Sobek, S. Schaver, H. Rehraver, D. Fischer, A. Patrignani, ETH Zurich (Switzerland);

S. Landgraf, Graz Univ. of Technology (Austria); R. Schlapbach, ETH Zurich (Switzerland)

$85960 Z$ Real-time point-of-care measurement of impaired renal function in a rat acute injury model employing exogenous fluorescent tracer agents [8596-36]

R. B. Dorshow, MediBeacon, LLC. (United States); R. M. Fitch, K. P. Galen, J. K. Wojdyla, A. R. Poreddy, J. N. Freskos, R. Rajagopalan, J.-J. Shieh, Covidien/Mallinckrodt (United States); S. G. Demirjian, Cleveland Clinic Foundation (United States)

859610 Molecular dynamics study of phospholipid biomacromolecules using a coarse-grained model [8596-37]

O. E. Glukhova, E. L. Kossovich, A. S. Kolesnikova, L. R. Menisheva, N.G. Chernyshevsky Saratov State Univ. (Russian Federation) 
859611 Development of the terahertz emitter model based on nanopeapod in terms of biomedical applications [8596-38]

O. E. Glukhova, I. S. Nefedov, A. S. Kolesnikova, M. M. Slepchenkov, O. A. Terentev,

V. V. Shunaev, N.G. Chernyshevsky Saratov State Univ. (Russian Federation)

859612 Carbon nanotube+graphene quantum dots complex for biomedical applications [8596-39]

O. E. Glukhova, I. N. Saliy, A. S. Kolesnikova, E. L. Kossovich, M. M. Slepchenkov,

N.G. Chernyshevsky Saratov State Univ. (Russian Federation)

859613 Docosahexaenoic acid conjugated near infrared flourescence probe for in vivo early tumor diagnosis [8596-40]

S. Li, J. Cao, J. Qin, X. Zhang, China Pharmaceutical Univ. (China); S. Achilefu, Washington Univ. School of Medicine in St. Louis (United States); Z. Qian, Nanjing Univ. of Aeronautics and Astronautics (China); Y. Gu, China Pharmaceutical Univ. (China)

859614 MUC1 aptamer based near infrared fluorescence probes for tumor diagnosis [8596-41]

J. Zhao, Y. Ma, S. Cui, J. Cao, China Pharmaceutical Univ. (China); S. Achilefu, Washington Univ. School of Medicine in St. Louis (United States); Y. Gu, China Pharmaceutical Univ. (China)

859615 Thermal-lens study of semiconductor nanoparticles embedded in restorative dental resin [8596-42]

L. P. Alves, Univ. Camilo Castelo Branco-UNICASTELO (Brazil); V. Pilla, Univ. Federal de Uberlândia (Brazil); A. N. Iwazaki, Univ. Camilo Castelo Branco-UNICASTELO (Brazil);

P. R. Barja, Univ. do Vale do Paraíba (Brazil); E. Munin, Univ. Camilo Castelo BrancoUNICASTELO (Brazil)

Author Index 


\title{
Conference Committee
}

\author{
Symposium Chairs
}

James Fujimoto, Massachusetts Institute of Technology

(United States)

R. Rox Anderson, Wellman Center for Photomedicine, Massachusetts General Hospital (United States) and Harvard School of Medicine (United States)

Program Track Chairs

Paras Prasad, SUNY/Buffalo (United States)

Dan V. Nicolau, The University of Liverpool (United Kingdom)

Conference Chairs

Samuel Achilefu, Washington University School of Medicine in St. Louis (United States)

Ramesh Raghavachari, U.S. Food and Drug Administration

(United States)

Conference Program Committee

Bohumil Bednar, Merck \& Company, Inc. (United States)

Mikhail Y. Berezin, Washington University School of Medicine in St.

Louis (United States)

Richard B. Dorshow, Covidien (United States)

Paul M. W. French, Imperial College London (United Kingdom)

Yueqing Gu, China Pharmaceutical University (China)

Hisataka Kobayashi, National Institutes of Health (United States)

Ashok Kumar Mishra, Indian Institute of Technology Madras (India)

D. Michael Olive, LI-COR Biosciences (United States)

Gabor Patonay, Georgia State University (United States)

Attila Tarnok, Universität Leipzig (Germany)

Yasuteru Urano, The University of Tokyo (Japan)

Session Chairs

Molecular Probes for Targeted Imaging and Therapy

Samuel Achilefu, Washington University School of Medicine in St. Louis (United States)

NIR Fluorescent Molecular Probes for Biological Imaging

Hisataka Kobayashi, National Institutes of Health (United States) 
Imaging Molecular Processes with Fluorescent Reporters

Gabor Patonay, Georgia State University (United States)

Nonbleaching and Ultrasmall Fluorescent Tags II: Joint Session with Conferences 8596 and 8635

Ramesh Raghavachari, U.S. Food and Drug Administration (United States)

Philip R. Hemmer, Texas A\&M University (United States)

Nanoparticles Design and Applications

Ramesh Raghavachari, U.S. Food and Drug Administration (United States)

Soft Nanoparticles for Biomedical Applications

Hisataka Kobayashi, National Institutes of Health (United States)

Hybrid Technologies for Molecular Imaging Applications

Richard B. Dorshow, Covidien (United States)

Molecular Approaches and Methods

Mikhail Y. Berezin, Washington University School of Medicine in St. Louis (United States) 